4. Doll HA, Petersen SE, Stewart-Brown SL. Obesity and physical and emotional well-being: associations between body mass index, chronic illness, and the physical and mental components of the SF-36 questionnaire. Obesity Research. 2000. 8. 160-170. DOI: 10.1038/oby.2000.17

DOI https://doi.org/10.30525/978-9934-26-038-4-4

\title{
CLINICAL FEATURES OF CORONAVIRUS DISEASE IN HOSPITALIZED PATIENTS
}

\author{
Afanasiuk O. I. \\ Ph. D. in Medicine, \\ Associate Professor at the Department of Internal Medicine № 3 \\ National Pirogov Memorial Medical University \\ Shmaliy V. I. \\ Ph. D. in Medicine, \\ Associate Professor at the Department of Internal Medicine № 3 \\ National Pirogov Memorial Medical University

\section{Shushkovska Yu. Yu.} \\ Ph. D. Applicant at the Department of Internal Medicine № 3 \\ National Pirogov Memorial Medical University \\ Vinnytsya, Ukraine
}

Coronavirus disease (CVD) is an acute respiratory infection caused by the severe acute respiratory syndrome virus 2 (SARS-CoV-2). The virus was identified as the cause of an outbreak of pneumonia of unknown origin in China, Wuhan City, Hubei Province, in December 2019. The clinical picture corresponds to a respiratory infection with varying severity of symptoms from a mild cold-like illness to severe viral pneumonia, leading to potentially fatal acute respiratory distress syndrome [1, p. 41]. Given the fact that humanity first encountered the manifestations of this need, the novelty of the clinic, diagnosis, continues research to study the peculiarities of the disease in different categories of people.

The aim is to study the clinical features of coronavirus infection in severe patients who remain in hospital.

Material and methods. Criteria for inclusion in the study: diagnosed with CVD by polymerase chain reaction, hospitalization for the introduction of 
bilateral pneumonitis by spiral computed tomography of the chest. Exclusion criteria were: suspicion of CVD, mild disease without pneumonitis.

30 case histories of patients who were hospitalized for CVD were analyzed. There were women -18 , men -12 among them. The average age was $71.67 \pm 0.8$ years. Among the complaints in the initial study dominated: shortness of breath, severe weakness, fever - in $100 \%$ of patients, the last complaint was in the range of $38.5-39.4{ }^{\circ} \mathrm{C}$, cough was noted in 25 patients, which was $83.33 \%$, although dry cough was present in all patients. Other complaints include headache, muscle aches, and nonspecific abdominal pain. No patient complained of loss of smell and taste. From the anamnesis it was noted that the average number of days from the onset of the disease to hospitalization was $7.8 \pm 0.28$ days. In addition, an important aspect of the history was that $53.33 \%$ of patients were in short-term contact with patients with coronavirus, but $46.67 \%$ of patients stated that they were not in contact with patients. Concomitant diseases in these patients were: overweight and obesity of various degrees in $100 \%$ of patients, chronic obstructive pulmonary disease $33.33 \%$, type II diabetes $46.67 \%$, chronic kidney disease $33.33 \%$, hypertension $83.33 \%$, heart failure with reduced ejection fraction $-40 \%$ patients, chronic myelogenous leukemia $-10 \%$. It should be noted that at the time of hospitalization, diabetes was in the phase of subcompensation or decompensation, which in turn contributed to a more severe somatic condition. On objective examination, cyanosis, oxygen saturation $68-91 \%$, respiratory rate 24-32 / min. Above the lungs - vesicular weakened breathing, wet rales. All patients with concomitant hypertension had normal or slightly reduced blood pressure at the time of hospitalization. In $43.33 \%$ of patients there was pain in the epigastric region, in 30\% - nonspecific pain throughout the abdomen on palpation. In the general analysis of blood the anemia of the first and second degrees prevailed and only in $6.67 \%$ - anemia of the third degree the average indicator of hemoglobin made 102,3 $\pm 1,92 \mathrm{~g} / \mathrm{l}$. Also, all patients had lymphopenia with a significantly reduced absolute number of lymphocytes $748 \pm 29.61 \mu \mathrm{l}$, increased erythrocyte sedimentation rate (ESR) $52.1 \pm 0.99 \mathrm{~mm} / \mathrm{h}$, platelets $390.5 \pm 9.93 * 10^{9} / 1$. In the biochemical analysis of blood there was a significant increase in C-reactive peptide $137.5 \pm$ $5.84 \mathrm{mg} / \mathrm{l}$, D-dimer $551.7 \pm 26.49 \mathrm{ng} / \mathrm{ml}$, interleukin-6 $190.3 \pm 25.68 \mathrm{pg} /$ $\mathrm{ml}$, in $93.33 \%$ - observed procalcitonin within normal limits. During treatment, which was prescribed according to the current protocol of the Ministry of Health, all patients developed various types of complications, including: acute cerebrovascular accident in 10\%, non-Q-myocardial infarction $6.67 \%$, pulmonary embolism low risk $-40 \%$, thrombosis of arterial vessels of the lower extremities $-6.67 \%$ on the background of high doses of antico- 
agulant therapy, respiratory distress syndrome $-20 \%$, spontaneous pneumothorax with the development of subcutaneous emphysema $-3.33 \%$, multiple organ failure $-13.33 \%$ psychomotor arousal $-6.67 \%$. In addition, one patient was diagnosed with chronic lymphocytic leukemia for the first time. One patient could have several complications that significantly worsened the course of the disease. The average duration of treatment was $16.0 \pm 0.47$ bed-days. $13.33 \%$ of patients died, the other $86.67 \%$ were discharged home. In addition, there was a direct correlation between severe CVD and overweight and various degrees of obesity, decompensation of diabetes, low oxygen saturation and absolute lymphopenia, which indicated the depletion of the body's compensatory mechanisms [2, p. 39] at the time of hospitalization, as well as high rates of inflammation (C-reactive peptide, interleukin-6, ESR) and high rates of thrombosis (platelets, D-dimer).

Conclusions. Thus, the severe course of coronavirus infection mainly occurs in elderly patients, regardless of gender, who have the impression of the cardiovascular system, decompensated type 2 diabetes, various degrees of obesity and depletion of the body's compensatory mechanisms, manifested by significantly reduced absolute lymphocyte counts. The clinical picture is represented by signs of intoxication syndrome and pulmonary insufficiency without signs of loss of taste and smell. Patients need to be hospitalized mainly one week after the onset of the disease, which may be due to the development of a cytokine storm, which leads to severe damage to the respiratory system and the development of various complications, which in turn contribute to fatal consequences associated with acute respiratory distress syndrome. and multiorgan failure.

\section{References:}

1. Андрейчин М.А., Ничик Н.А., Завіднюк Н.Г., Йосик Я.I., Іщук I.C., Івахів О.Л. COVID-19: епідеміологія, клініка, діагностика, лікування та профілактика. Інфекиійні хвороби. 2020. № 2(100). C. $41-55$.

2. Комісаренко С.В. Полювання вчених на коронавірус sars-cov-2, що викликає COVID-19: наукові стратегії подолання пандемії. Bicн. НАН України. 2020. № 8. С. 29-71. 